\title{
Analisis Pengaruh Perilaku Konsumen dan Periklanan terhadap Keputusan Pembelian Mobil Suzuki Ertiga di Sumatera Barat pada PT. Elang Perkasa Motor
}

\author{
Ramadhania \\ ramadhania010589@gmail.com \\ Universitas Tamansiswa Padang \\ Herry Hardian \\ herryhardian96@gmail.com \\ Universitas Tamansiswa Padang
}

\begin{abstract}
Abstrak
Tujuan dari penelitian ini adalah untuk mengetahui pengaruh perilaku konsumen dan periklanan terhadap keputusan pembelian mobil Suzuki Ertiga di Sumatera Barat. Populasi adalah seluruh konsumen yang telah membeli mobil Suzuki Ertiga di Sumatera Barat dan sampel berjumlah 100 orang responden. Sedangkan teknik analisis data yang digunakan dalam penelitian ini adalah regresi linear berganda, uji $t$, uji $F$ dan koefisien determinasi. Berdasarkan hasil uji t yang dilakukan didapatkan variabel perilaku konsumen berpengaruh terhadap keputusan pembelian mobil Suzuki Ertiga di Sumatera Barat pada PT. Elang Perkasa Motor dengan nilai signifikansi sebesar 0,03 <0,05. Variabel periklanan berpengaruh terhadap keputusan pembelian dengan nilai signifikansi sebesar 0,00 < 0,05. Berdasarkan hasil uji $F$ yang dilakukan sebesar 49,119 dan nilai signifikansi 0,00<0,05 serta nilai koefisien determinasi variabel perilaku konsumen dan periklanan sebesar 49,3\% dan sisanya 50,7\% dijelaskan oleh variabel lain yang tidak diteliti dalam penelitian ini seperti brand image, kualitas produk dan harga.
\end{abstract}

Kata kunci : perilaku konsumen, periklanan, keputusan pembelian.

\section{Pendahuluan}

Perkembangan usaha kini telah diwarnai dengan berbagai macam persaingan di segala bidang. Salah satunya adalah persaingan bisnis yang semakin ketat yang mengakibatkan perubahan perilaku konsumen di dalam mengambil keputusan untuk membeli suatu produk. Mengingat perkembangan teknologi yang semakin dinamis, manusia dituntut dengan cepat dan tepat untuk bertindak agar tidak kalah bersaing. Melihat kondisi tersebut menyebabkan pebisnis semakin dituntut untuk mempunyai strategi yang tepat dalam memenuhi target volume penjualan. Untuk itu, setiap perusahaan harus memahami perilaku konsumen pada pasar sasarannya karena kelangsungan hidup perusahaan tergantung pada perilaku konsumennya. Perilaku konsumen merupakan hal-hal yang mendasari konsumen untuk membuat keputusan pembelian ketika memilih suatu barang atau jasa akan memikirkan terlebih dahulu mulai dari harga, kualitas, fungsi, atau kegunaan barang tersebut.

Pembelian atas sebuah produk sangat dipengaruhi oleh perilaku konsumen itu sendiri, diantaranya dilihat dari profesi, tempat tinggal maupun pengetahuan konsumen dalam mendapatkan info produk yang akan dibelinya. Permasalahan yang terjadi pada Suzuki Ertiga disebabkan oleh semakin banyaknya pesaing sehingga konsumen merasa mudah untuk mencari yang mereka inginkan, dan menentukan keputusan pembelian konsumen pada Suzuki Ertiga. Konsumen lebih mempertimbangkan kepuasan pada dirinya karena masih banyak perusahaan otomotif lain. Dalam persaingan masing-masing perusahaan harus dapat memenangkan persaingan 
dengan menampilkan produk yang terbaik dan dapat memenuhi selera konsumen yang selalu berkembang dan berubah-ubah. Seiring dengan perkembangan zaman dan semakin meningkatnya kebutuhan, dukungan sarana transportasi membawa angin segar bagi perusahaan otomotif terutama di bidang industri mobil, yang mana kini sudah semakin dibutuhkan oleh banyak orang. Persaingan yang semakin ketat terjadi di dalam dunia otomotif khususnya produk mobil karena produk ini merupakan alat transportasi darat yang mulai diincar oleh masyarakat.

Salah satu pabrikan mobil dunia adalah Suzuki. Suzuki sudah berpengalaman selama puluhan tahun dalam hal memproduksi mobil. Salah satu produk mobil Suzuki yang dirakit dan dipasarkan di Indonesia adalah Suzuki Ertiga. Suzuki Ertiga adalah salah satu produk Suzuki yang paling laris di Indonesia. Suzuki Ertiga sudah terbukti aman, mewah, irit dan nyaman (AMIN) di kendarai di Indonesia. Suzuki Ertiga termasuk salah satu mobil idaman keluarga adalah mobil berjenis MPV yang diproduksi oleh Suzuki sejak tahun 2012. Nama Ertiga berasal dari bahasa Indonesia, yaitu gabungan dari Er (dari huruf R) yang berarti Row (baris) dan Tiga yang berarti angka 3, berarti mobil yang memiliki 3 baris pada interiornya dengan kapasitas 7 orang penumpang dewasa 7- seater seperti MPV (Multi Purpose Vehicle). Suzuki Ertiga merupakan perpaduan MPV dan Sedan, yakni dengan platform Suzuki Swift generasi ketiga.

Ertiga dipasarkan prinsipal oleh Suzuki Motor Corporation Jepang secara global. Mazda juga pernah memasarkan Suzuki Ertiga generasi pertama di Indonesia sebagai Mazda VX-1. Selain itu, Proton juga pernah memasarkan Suzuki Ertiga generasi pertama di Malaysia sejak tanggal 24 November 2016 sebagai Proton Ertiga. Suzuki Ertiga hadir pada mulanya berupa mobil konsep dengan nama R-III digelaran Indonesia International Motor Show (IIMS) 2010 dan tampil perdana secara global premiere di ajang Auto Expo 2012, New Delhi pada awal Januari 2012 silam dengan nama resmi, Suzuki Ertiga. Mobil Suzuki Ertiga ini menggunakan sistem penggerak roda depan (Front Wheel Drive/ FWD) dan dengan sasis monokok. Suzuki Indomobil Motor Indonesia memiliki 325 dealer yang tersebar di seluruh Indonesia. Salah satunya di Kota Padang, Sumatera Barat yaitu Suzuki PT. Elang Perkasa Motor Khatib Sulaiman dan dealer ini satu-satunya holding di Provinsi ini. Kota Padang atau lebih luasnya Minangkabau sudah terkenal sejak dulu melalui cerita-cerita tentang perantau minang atau Padang yang pergi merantau untuk berdagang (www.wikipedia.com).

Dengan terjadinya penurunan penjualan Mobil Suzuki Ertiga PT. Elang Perkasa tersebut, membuat perusahaan lebih memaksimalkan dalam memasarkan atau mempertahankan keberadaan produk dalam segmen pasar yang dimasuki. Untuk memasuki segmen pasar, PT. Elang Perkasa Motor menggunakan beberapa cara bauran promosi untuk menawarkan produk kepada konsumen. Selain perilaku konsumen, keputusan pembelian juga dipengaruhi oleh periklanan. Program periklanan adalah salah satu bentuk dari komunikasi interpersonal yang digunakan oleh kegiatan penjualan dan pemasaran dalam rangka menginformasikan dan mendorong permintaan terhadap produk, jasa, dan ide dari perusahaan dengan cara mempengaruhi konsumen agar mau membeli produk dan jasa yang dihasilkan oleh perusahaan. Periklanan yang telah dilakukan oleh PT. Elang Perkasa Motor terlihat pada tabel 1 sebagai berikut: 
Tabel 1 Bentuk Periklanan PT. Elang Perkasa Motor Padang

\begin{tabular}{|c|c|c|c|}
\hline No & Jenis Promosi & Kegiatan Promosi & Keterangan \\
\hline \multirow{3}{*}{1} & \multirow{3}{*}{$\begin{array}{l}\text { Periklanan } \\
(\text { Advertising) }\end{array}$} & Spanduk 4x1 & $\begin{array}{l}\text { 1. } 30 \text { dalam kota padang } \\
\text { 2. } 20 \text { di luar kota padang }\end{array}$ \\
\hline & & $\begin{array}{c}\text { Billboard } \\
5 \times 10 \mathrm{~m} \text { dan } 6 \times 12\end{array}$ & $\begin{array}{l}\text { 1. Kota Padang } \\
\text { 2. Kota Solok } \\
\text { 3. Kabupaten Pesisir Selatan } \\
\text { 4. Kota Bukittinggi } \\
\text { 5. Kota Payakumbuh } \\
\text { 6. Kabupaten Padang Pariaman }\end{array}$ \\
\hline & & Iklan Media & $\begin{array}{l}\text { 1. Stasiun TV Nasional } \\
\text { 2. Padang TV } \\
\text { 3. Koran Padang Ekspres } 10 \times 150 \\
\text { 4. Koran Haluan 10x150mm } \\
\text { 5. Radio Padang FM } \\
\text { 6. Radio Classy FM }\end{array}$ \\
\hline
\end{tabular}

Sumber: PIC Marketing Area PT.Elang Perkasa Motor, 2019

Berdasarkan tabel di atas dapat ditarik kesimpulan bahwa program promosi yang dilakukan oleh PT. Elang Perkasa Motor Padang, dapat menarik keputusan konsumen dalam melakukan pembelian mobil Suzuki Ertiga. Program bauran promosi yang sering dilakukan PT. Elang Perkasa Motor adalah periklanan (advertising), karena periklanan adalah salah satu media promosi yang sering dilihat oleh konsumen. Untuk meyakinkan konsumen, perusahaan harus mampu berkomunikasi dengan baik agar konsumen tertarik dengan produk yang dipasarkan. Salah satunya adalah dengan menyiapkan strategi-strategi promosi, karena promosi sangat berpengaruh terhadap keputusan pembelian konsumen dan mempengaruhi volume penjualan jika dijalankan dengan baik. Dengan kata lain, semakin baik dan meningkatnya strategi promosi yang dilakukan maka semakin meningkat pula keputusan pembelian konsumen, sehingga berdampak pada peningkatan volume penjualan produk. Adapun Fluktuasi penjualan PT. Elang Perkasa Motor Khatib Sulaiman di Kota Padang bisa dilihat pada gambar berikut ini :

\section{Gambar 1 Data Penjualan Suzuki Ertiga di Sumatera Barat}

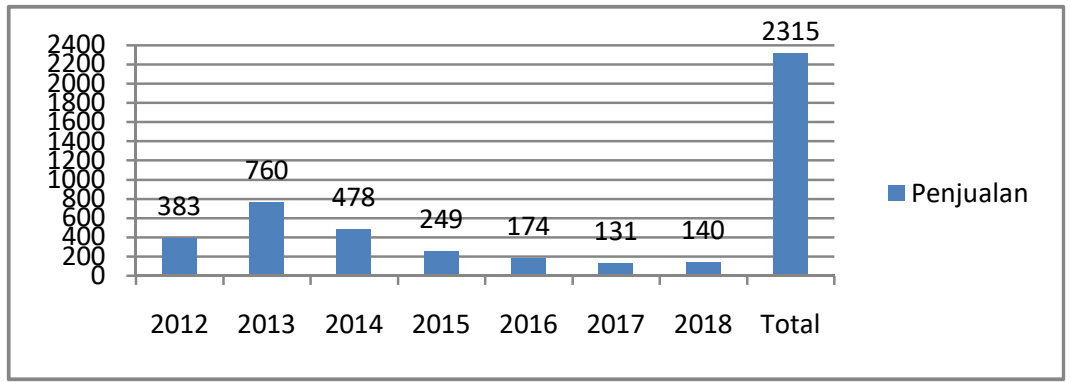

Sumber: PIC Marketing Area PT.Elang Perkasa Motor, 2019

Berdasarkan grafik di atas dapat ditarik kesimpulan bahwa tingkat penjualan Suzuki Ertiga di Kota Padang mengalami penurunan yang sangat drastis. Bagi perusahaan ini adalah masalah serius. Perusahaan harus mengambil keputusan untuk mengatasi permasalahan ini. Penurunan penjualan Suzuki Ertiga dikarenakan banyak pesaing dari kompetitor dengan harga yang ditawarkan lebih murah, dan juga persepsi dari masyarakat yang ingin mencoba sesuatu yang baru dan menarik. Keputusan pembelian merupakan suatu konsep dalam perilaku pembelian dimana konsumen memutuskan untuk bertindak atau melakukan sesuatu dalam hal melakukan pembelian ataupun memanfaatkan produk atau jasa tertentu. Kebanyakan konsumen baik konsumen individu maupun pembeli organisasi melalui proses mental yang hampir sama dalam memutuskan produk 
dan merek apa yang akan dibeli. Dalam melakukan keputusan pembelian biasanya hal pertama yang dipertimbangkan konsumen dalam memilih produk adalah dengan melihat bauran promosi.

Perusahaan harus memperhatikan faktor-faktor keputusan pembelian supaya strategi pemasaran dapat berjalan lebih efektif dibandingkan para pesaing agar produk tersebut tetap dipilih oleh konsumen dalam hal ini faktor budaya, faktor sosial, faktor pribadi dan faktor psikologi dalam rangka penggunaan periklanan memiliki peran yang sangat penting bagi konsumen dalam melakukan keputusan pembelian. Dalam sebuah produk pasti terdapat unsur-unsur periklanan yang dapat mempengaruhi konsumen dalam melakukan keputusan pembelian yaitu surat kabar, radio, televisi, papan reklame, surat langsung. Hal tersebut menjadikan bahan pertimbangan paling utama bagi konsumen sebelum melakukan keputusan pembelian pada satu produk.

\section{Kajian Pustaka}

\subsection{Perilaku Konsumen}

Menurut (Schiffman \& Kanuk, 2007), perilaku konsumen adalah meliputi semua tindakan untuk mencari, membeli, menggunakan, mengevaluasi dan menghabiskan produk. Menurut (Abdullah \& Tantri, 2016), perilaku konsumen adalah suatu tindakan yang langsung terlibat dalam mendapatkan, mengkonsumsi dan menghabiskan produk dan jasa, termasuk keputusan mendahului dan menyusuli tindakan ini.

Menurut (Schiffman \& Kanuk, 2007), perilaku konsumen adalah meliputi semua tindakan untuk mencari, membeli, menggunakan, mengevaluasi dan menghabiskan produk. Perilaku konsumen dapat digolongkan dalam beberapa dimensi meliputi:

1) Keinovatifan konsumen

2) Dogmatisme

3) Karakter sosial

4) Tingakat stimulasi optimum

5) Pencari variasi atau kesenangan baru

\subsection{Periklanan}

Periklanan menurut (Sunyoto, 2012) didefinisikan sebagai segala bentuk penyajian non personal dan promosi ide, barang, atau jasa oleh suatu sponsor tertentu yang memerlukan pembayaran, dalam membuat program periklanan manajemen pemasaran selalu memulai dengan mengidentifikasi pasar sasaran dan motif pembeli. Menurut (Alma, 2011) iklan adalah bentuk komunikasi tidak langsung, didasari pada informasi tentang keunggulan atas suatu produk. Menurut (Sangadji \& Sopiah, 2013), merupakan salah satu bentuk dari komunikasi impersonal yang digunakan oleh perusahaan barang atau jasa. Menurut (Kotler dan Keller, 2017) bahwa periklanan merupakan upaya perusahaan menyajikan atau menyampaikan pesan promosi non-personal untuk mempengaruhi konsumen untuk membeli produk yang ditawarkan. mengemukakan indikator periklanan meliputi :

1) Presentasi umum (public presentasion)

2) Tersebar luas(pervasiveness)

3) Daya ungkap yang kuat (expresiveness)

\subsection{Keputusan Pembelian}

Menurut (Sangadji \& Sopiah, 2013), keputusan pembelian adalah keputusan konsumen mengenai apa yang dibeli, apakah membeli atau tidak, kapan membeli, dimana membeli, dan bagaimana cara membayarnya. Menurut (Kotler dan Keller, 2017), dalam melakukan keputusan pembelian, konsumen banyak dipengaruhi oleh berbagai faktor pengambilan keputusan pembelian merupakan suatu kegiatan individu yang secara langsung terlibat dalam mendapatkan dan mempergunakan barang yang ditawarkan. Menurut (Tjiptono, 2014) keputusan pembelian 
merupakan tahapan proses akhir dari serangkaian tahapan proses yang terjadi pada perilaku konsumen serta mengkonsumsinya. Menurut (Sangadji \& Sopiah, 2013), Indikator keputusan konsumen yaitu :

1) Pemilihan produk

2) Pemilihan merek

3) Pemilihan tempat penyalur

4) Waktu Pembelian

5) Jumlah Pembelian

6) Metode Pembayaran

\section{Kerangka Konseptual}

Untuk memudahkan suatu penelitian maka perlu dibuat suatu kerangka pikir penelitian yang menggambarkan suatu hubungan variabel independen terhadap variabel dependen. Berdasarkan telaah pustaka terhadap variabel-variabel diatas dalam penelitian ini mengenai analisis perilaku konsumen dan periklanan terhadap keputusan pembelian, maka dapat ditampilkan pemikiran teoritis sebagai berikut :

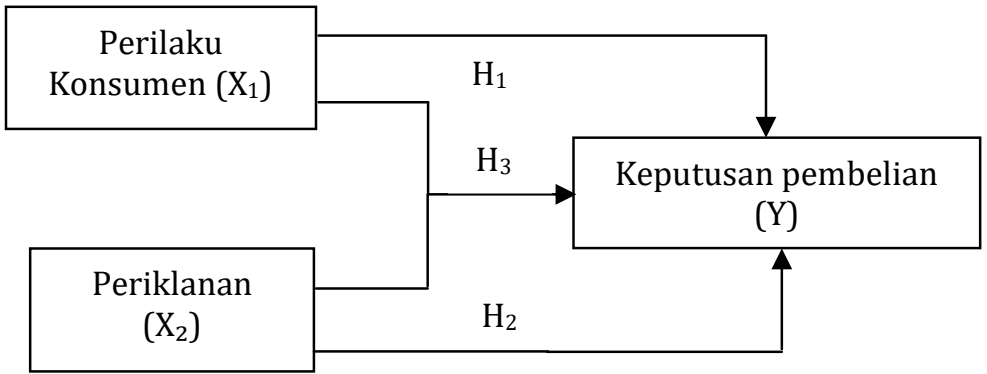

Gambar 2. Kerangka Pemikiran Konseptual

\section{Metode Penelitian}

\subsection{Jenis Penelitian}

Jenis penelitian yang digunakan adalah kuantitatif deskriptif. Penelitian kuantitatif bertujuan untuk membuktikan ada/tidak adanya pengaruh signifikan antara variabel bebas dengan variabel terikat dalam penelitian ini. Variabel bebas dalam penelitian ini adalah perilaku konsumen dan periklanan sedangkan variabel terikatnya adalah keputusan pembelian. Penelitian deskriptif bertujuan memberikan gambaran mengenai perilaku konsumen, periklanan dan keputusan pembelian mobil Suzuki Ertiga di Sumatera Barat pada PT. Elang Perkasa Motor.

\subsection{Populasi dan Sampel}

Populasi pada penelitian ini adalah seluruh konsumen yang telah membeli mobil Suzuki Ertiga sejak tahun 2012 sampai 2018 di Sumatera Barat. Menurut (Sugiyono, 2012) mengatakan bahwa, sampel adalah bagian dari jumlah dan karakteristik yang dimiliki oleh populasi tersebut. Pengambilan sampel pada penelitian ini menggunakan teknik simple random sampling, yaitu menentukan sampel yang populasinya besar dan jumlahnya tidak diketahui. Berdasarkan teknik pengambilan sampel tersebut maka didapat sampel dalam penelitian ini sebanyak 100 orang sampel. 


\section{Analisis Data dan Pembahasan}

\subsection{Analisis Data}

\subsubsection{Hasil Analisis Regresi Linier Berganda}

Hasil pengujian persamaan regresi linier berganda untuk pengaruh perilaku konsumen dan periklanan secara bersamaan terhadap keputusan pembelian mobil Suzuki Ertiga di Sumatera Barat pada PT. Elang Perkasa Motor dapat dilihat pada tabel 4.1

Tabel 4. Hasil Pengujian Regresi Linier Berganda

\begin{tabular}{|c|c|c|c|c|c|c|}
\hline \multicolumn{7}{|c|}{ Coefficients $^{a}$} \\
\hline & \multirow[t]{2}{*}{ Model } & \multicolumn{2}{|c|}{$\begin{array}{l}\text { Unstandardized } \\
\text { Coefficients }\end{array}$} & \multirow{2}{*}{$\begin{array}{c}\begin{array}{c}\text { Standardized } \\
\text { Coefficients }\end{array} \\
\text { Beta }\end{array}$} & \multirow[b]{2}{*}{$\mathrm{t}$} & \multirow[t]{2}{*}{ Sig. } \\
\hline & & B & Std. Error & & & \\
\hline \multirow[t]{3}{*}{1} & (Constant) & 17,336 & 3,331 & & 5,205 & ,000 \\
\hline & Perilaku_konsumen & ,347 & 112 & 265 & 3,103 & 003 \\
\hline & Periklanan & ,857 & 138 & ,529 & 6,205 & ,000 \\
\hline
\end{tabular}

Sumber : Data diolah

Berdasarkan tabel 4 di atas, maka diperoleh hasil persamaan regresi sebagai berikut:

$$
Y=17,336+0,347 X_{1}+0,857 X_{2}+e
$$

Berdasarkan persamaan tersebut dapat dianalisis beberapa hal, antara lain:

1) Nilai constanta Nilai konstanta adalah 17,336 artinya ada atau tidak ada perubahan variabel perilaku konsumendan periklanan (nilai $\mathrm{X}_{1}$ dan $\mathrm{X}_{2}$ adalah 0) maka keputusan pembelian pada PT. Elang Perkasa Motor Padang sudah ada sebesar17,336 satuan.

2) Nilai koefisien regresi perilaku konsumen adalah 0,347 artinya jika variabel perilaku konsumen $\left(\mathrm{X}_{1}\right)$ meningkat sebesar 1 (satuan) dengan asumsi variabel periklanan $\left(\mathrm{X}_{2}\right)$ dan konstanta (a) adalah 0 (nol), maka keputusan pembelian pada responden PT. Elang Perkasa Motor Padang meningkat sebesar 0,347.

3) Nilai Koefisien regresi periklanan adalah 0,857 artinya jika variabel periklann $\left(\mathrm{X}_{2}\right)$ meningkat sebesar 1 (satuan) dengan asumsi variabel perilaku konsumen $\left(\mathrm{X}_{1}\right)$ dan konstanta (a) adalah 0 (nol), maka keputusan pembeliandi PT. Elang Perkasa Motor Padangmeningkat sebesar 0,857.

\subsubsection{Hasil Uji t}

Menurut (Sugiyono, 2012), uji ini digunakan untuk mengetahui pengaruh masing-masing variabel bebas terhadap variabel terikat secara parsial (individu) dengan tingkat kesalahan 5\%. Berdasarkan uji t yang dilakukan dapat dilihat pada tabel 2 di bawah ini:

Tabel 2. Hasil Uji t

\begin{tabular}{|c|c|c|c|c|c|c|}
\hline \multicolumn{7}{|c|}{ Coefficients ${ }^{a}$} \\
\hline & \multirow[t]{2}{*}{ Model } & \multicolumn{2}{|c|}{$\begin{array}{l}\text { Unstandardized } \\
\text { Coefficients }\end{array}$} & \multirow{2}{*}{$\begin{array}{c}\begin{array}{c}\text { Standardized } \\
\text { Coefficients }\end{array} \\
\text { Beta }\end{array}$} & \multirow[b]{2}{*}{$\mathrm{t}$} & \multirow[t]{2}{*}{ Sig. } \\
\hline & & B & Std. Error & & & \\
\hline \multirow[t]{3}{*}{1} & (Constant) & 17,336 & 3,331 & & 5,205 & ,000 \\
\hline & Perilaku_konsumen & ,347 & ,112 & ,265 & 3,103 & ,003 \\
\hline & Periklanan & 857 & 138 & ,529 & 6,205 & ,000 \\
\hline
\end{tabular}

Sumber: Data diolah 
Berdasarkan tabel 4.2, maka dapat diketahui dan disimpulkan sebagai berikut:

1) Pengaruh Variabel Perilaku Konsumen Terhadap Keputusan Pembelian

Variabel perilaku konsumen $\left(\mathrm{X}_{1}\right)$ berpengaruh signifikan terhadap keputusan pembelian mobil Suzuki Ertiga di kota padang pada PT. Elang Perkasa Motor. Hal ini diketahui dari nilai $t_{\text {hitung }}>t_{\text {tabel }}$ atau $(3,103>1,661)$ dan nilai signifikansi sebesar $0,03<0,05$, maka $\mathrm{H}_{0}$ ditolak dan $\mathrm{H}_{1}$ diterima.

2) Pengaruh Variabel Periklanan Terhadap Keputusan Pembelian

Variabel periklanan $\left(\mathrm{X}_{2}\right)$ berpengaruh signifikan terhadap keputusan pembelian mobil Ertiga di kota padang pada PT. Elang Perkasa Motor. Hal ini diketahui dari nilai $t_{\text {hitung }}>t_{\text {tabel }}$ $(6,205>1,661)$ dan nilai signifikan yang dihasilkan sebesar $0,00<0,05$, maka $\mathrm{H}_{0}$ ditolak dan $\mathrm{H}_{2}$ diterima.

\subsubsection{Hasil Uji F}

Menurut (Sugiyono, 2012), uji ini digunakan untuk mengetahui apakah variabel independen secara bersama-sama berpengaruh secara signifikan terhadap variabel dependen. Berdasarkan uji $\mathrm{F}$ yang dilakukan dapat dilihat pada tabel 3 di bawah ini.

Tabel 3. Hasil Uji F

\begin{tabular}{|l|l|r|r|r|r|c|}
\hline \multicolumn{7}{|c|}{ ANOVA $^{\mathbf{b}}$} \\
\hline \multirow{2}{*}{ Model } & Sum of Squares & df & Mean Square & F & \multicolumn{1}{c|}{ Sig. } \\
\hline \multirow{2}{*}{1} & Regression & 808.554 & 2 & 404.277 & 49.119 & $.000^{\mathrm{a}}$ \\
\cline { 2 - 7 } & Residual & 798.356 & 97 & 8.230 & & \\
\cline { 2 - 7 } & Total & 1606.910 & 99 & & & \\
\hline
\end{tabular}

a. Predictors: (Constant), perilaku_konsumen,periklanan

b. Dependent Variable: Keputusan_pembelian

Berdasarkan hasil uji F pada tabel 4.3 di atas dapat diketahui bahwa nilai Fhitung sebesar 49,119 dengan nilai Ftabel df1 = k- $1(3-1=2)$, df2 = n - k (100 - $3=97)$ adalah 3,09 sehingga nilai Fhitung > Ftabel atau $(49,119>3,09)$ dan tingkat signifikansi 0,000 < 0,05 maka H0 ditolak dan H3 diterima sehingga dapat disimpulkan bahwa variabel perilaku konsumen (X1) dan periklanan (X2) secara bersamaan berpengaruh signifikan terhadap keputusan pembelian mobil Suzuki Ertiga di kota Padang pada PT. Elang perkasa Motor.

\subsubsection{Hasil Uji Koefisien Determinasi $\left(R^{2}\right)$}

Tabel 4. Hasil Uji koefisien Determinasi

\begin{tabular}{|l|r|r|r|r|}
\hline & & & \multicolumn{1}{|c|}{$\begin{array}{c}\text { Adjusted R } \\
\text { Square }\end{array}$} & \multicolumn{2}{c|}{$\begin{array}{c}\text { Std. Error of the } \\
\text { Estimate }\end{array}$} \\
\hline 1 & $\mathrm{R}$ & R Square & \multicolumn{1}{c|}{.493 } & 2.869 \\
\hline
\end{tabular}

a. Predictors: (Constant), perilaku_konsumen, periklanan

Berdasarkan tabel 4.4 dapat diketahui bahwa nilai koefisien determinasi terlihat pada nilai Adjusted R-Square sebesar 0,493. Hasil ini berarti terdapat hubungan pengaruh antara variabel perilaku konsumen dan periklanan terhadap keputusan pembelian, mobil Suzuki Ertiga di kota Padang pada PT. Elang Perkasa Motor sebesar 49,3\% sedangkan sisanya 50,7\% dijelaskan oleh variabel lain yang tidak diteliti dalam penelitian ini seperti brand image, kualitas produk dan harga. 


\subsection{Pembahasan Hasil Penelitian}

\subsubsection{Pengaruh Perilaku Konsumen Terhadap Keputusan Pembelian.}

Berdasarkan hasil pengujian hipotesis, diketahui bahwa perilaku konsumen $\left(\mathrm{X}_{1}\right)$ berpengaruh signifikan terhadap keputusan pembelian (Y) mobil Suzuki Ertiga di kota Padang pada PT. Elang Perkasa Motor, dengan nilai signifikansi sebesar 0,03<0,05 dan nilai thitung $>$ ttabel $(3,103$ $>1,661$ ), maka dapat disimpulkan bahwa $\mathrm{H}_{0}$ ditolak $\mathrm{H}_{1}$ diterima. Hal ini dapat disimpulkan bahwa perilaku konsumen mempengaruhi keputusan pembelian karena mobil Suzuki Ertiga sangat cocok untuk keluarga.

\subsubsection{Pengaruh periklanan terhadap Keputusan Pembelian}

Berdasarkan hasil pengujian hipotesis, diketahui bahwa periklanan $\left(\mathrm{X}_{2}\right)$ berpengaruh secara positif dan signifikan terhadap keputusan pembelian (Y) mobil Suzuki Ertiga di kota Padang di PT. Elang perkasa motor, dengan nilai signifikan sebesar $0,00<0,05$ dan thitung $>$ ttabel sebesar $6,205>1,661$. Hal ini dapatdisimpulkan bahwa H0 ditolak dan H2 diterima. Berdasarkan hasil hipotesis di atas dapat disimpulkan bahwa periklanan mempengaruhi keputusan pembelian mobil Suzuki Ertiga di kota Padang pada PT. Elang Perkasa Motor. Berdasarkan hasil penelitian tersebut dapat disimpulkan bahwa periklanan pada PT. Elang Perkasa Motor Padang berpengaruh terhadap keputusan pembelianmobil Suzuki Ertiga, sehingga iklan mobil Suzuki Ertiga memberikan informasi tentang kenyamanan keluarga dalam berkendara.

\subsubsection{Pengaruh Perilaku Konsumen dan Periklanan Terhadap Keputusan Pembelian}

Berdasarkan hasil uji hipotesis terbukti bahwa variabel perilaku konsumen $\left(\mathrm{X}_{1}\right)$ dan periklanan $\left(\mathrm{X}_{2}\right)$ secara bersamaan berpengaruh signifikan terhadap keputusan pembelian (Y) mobil Suzuki Ertiga di kota Padang pada PT. Elang Perkasa Motor. Hal ini terlihat dari nilai Fhitung sebesar 49,119 dengan nilai Ftabeldf1 = k- $1(3-1=2)$, df2 = $\mathrm{n}-\mathrm{k}(100-3=97)$ adalah 3,09 sehingga nilai Fhitung > Ftabel atau $(49,119>3,09)$ dan tingkat signifikansi 0,000<0,05 maka H0 ditolak dan H3 diterima.Dengan adanya pengaruh secara bersamaan perilaku konsumen dan periklanan terhadap keputusan pembelian mobil Suzuki Ertiga di kota Padang pada PT. Elang Perkasa Motor.

Hasil uji koefisien determinasi terdapat pada nilai Adjusted R Square sebesar 0,493. Hasil ini berarti terdapat hubungan pengaruh antara variabel perilaku konsumen dan periklanan terhadap keputusan pembelian, mobil Suzuki Ertiga di kota Padang pada PT. Elang Perkasa Motor sebesar 49,3\% sedangkan sisanya 50,7\% dijelaskan oleh variabel lain yang tidak diteliti dalam penelitian ini seperti brand image, kualitas produk dan harga.

\section{Kesimpulan dan Rekomendasi}

\subsection{Kesimpulan}

Berdasarkan hasil penelitian dan pembahasannya, maka dapat diambil kesimpulan sebagai berikut:

1) Variabel perilaku konsumen berpengaruh terhadap keputusan pembelian mobil Suzuki Ertiga di Sumatera Barat pada PT. Elang Perkasa Motor. Hal ini diketahui dari nilai $t_{\text {hitung }}>$ $t_{\text {tabel }}(3,103>1,661)$ dan nilai signifikansi sebesar $0,03<0,05$.

2) Variabel periklanan berpengaruh terhadap keputusan pembelian mobil Suzuki Ertiga di Sumatera Barat pada PT. Elang Perkasa Motor. Hal ini diketahui dari nilai $t_{\text {hitung }}>t_{\text {tabel }}(6,205$ $>1,661$ ) dan nilai signifikansi sebesar $0,00<0,05$.

3) Variabel perilaku konsumen dan periklanan secara bersama-sama berpengaruh terhadap keputusan pembelian mobil Suzuki Ertiga di Sumatera Barat pada PT. Elang Perkasa Motor. Hal ini diketahui dari nilai $F_{\text {hitung }}>F_{\text {tabel }}(49,119>3,09)$ dan nilai signifikansi 0,00<0,05.

4) Hasil koefisien determinasi memiki nilai adjusted $R$-Square sebesar 0,493.Hal ini berarti terdapat hubungan antara variabel perilaku konsumen dan periklanan terhadap keputusan 
pembelian mobil Suzuki Ertiga di Sumatera Barat pada PT. Elang Perkasa Motor sebesar 49,3\% sedangkan sisanya 50,7\% dan sisanya dipengaruhi oleh variabel lain yang tidak diteliti dalam penelitian ini seperti brand image, kualitas produk dan harga.

\subsection{Rekomendasi}

1) Sebaiknya PT. Elang Perkasa Motor terus melakukan evaluasi dengan cara meningkatkan pemberian kualitas pelayanan kepada konsumen seperti memberikan fasilitas ruang tunggu yang nyaman, memberikan makanan dan minuman kepada konsumen yang berada di showroom dan service.

2) Diharapkan karyawan PT. Elang Perkasa Motor Padang terus memberikan informasi penjelasan kelebihan inovasi terbaru dari Suzuki Ertiga, sehingga konsumen merasa ingin membeli mobil Suzuki Ertiga.

3) Diharapkan tim Suzuki memberikan inovasi terbaru pada mobil Ertiga sehingga dapat meningkatkan keputusan pembelian.

4) Diharapkan karyawan PT. Elang Perkasa terus meningkatkan informasi langsung ke perumahan atau door to door bahwa mobil Suzuki Ertiga adalah mobil keluarga.

\section{Daftar Pustaka}

Abdullah, T., \& Tantri, F. (2016). Manajemen Pemasaran. Yogyakarta: Rajawali Pers.

Alma, B. (2011). Manajemen Pemasaran dan Pemasaran Jasa. Bandung: Alfabeta.

Kotler dan Keller. (2017). Manajemen Pemasaran, Edisi 12, Jilid 1, PT.Indeks,. Jakarta. In $e$ - Jurnal Riset Manajemen.

Sangadji, E. M., \& Sopiah. (2013). Perilaku Konsumen : Pendekatan Praktis Disertai Himpunan Jurnal Penelitian. Yogyakarta: Penerbit Andi.

Schiffman, L., \& Kanuk, L. L. (2007). Perilaku Konsumen Edisi Kedua. Jakarta: PT. Indeks Gramedia. Sugiyono. (2012). Metode Penelitian Kuantitatif, Kualitatif dan R \& D.Bandung:Alfabeta. Metode Penelitian Kuantitatif, Kualitatif Dan R \& D.Bandung:Alfabeta.

https://doi.org/10.1017/CB09781107415324.004

Sunyoto, D. (2012). Dasar-Dasar Manajemen Pemasaran (Konsep, Strategi dan Kasus). Yogyakarta: CAPS.

Tjiptono, F. (2014). Pemasaran Jasa - Prinsip, Penerapan, dan Penelitiab. Bandung: Penerbit Andi. 
TARGET : JURNAL MANAJEMEN DAN BISNIS | e-ISSN : 2715-9361 | Vol. 2 No. 2 | Desember 2020

DOI https://doi.org/10.30812/target.v2i2.969 